\title{
Article \\ Effect of Banana Bunchy Top Virus on the Heat Shock Protein Genes of Pentalonia nigronervosa during Temperature Susceptibility and Its Effect on Virus Transmission
}

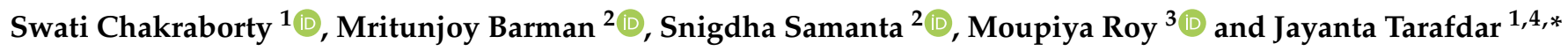 \\ 1 Department of Plant Pathology, Bidhan Chandra Krishi Viswavidyalaya, Mohanpur 741252, India; \\ swatichak777.sc@gmail.com \\ 2 Department of Agricultural Entomology, Bidhan Chandra Krishi Viswavidyalaya, Mohanpur 741252, India; \\ mritubarman@gmail.com (M.B.); snigdhamanu23@gmail.com (S.S.) \\ 3 Department of Agricultural Statistics, Bidhan Chandra Krishi Viswavidyalaya, Mohanpur 741252, India; \\ moupiyaroy12345@gmail.com \\ 4 Directorate of Research, Bidhan Chandra Krishi Viswavidyalaya, Kalyani 741235, India \\ * Correspondence: tarafdar.jayanta@bckv.edu.in; Tel.: +91-9830342320
}

check for

updates

Citation: Chakraborty, S.; Barman, M.; Samanta, S.; Roy, M.; Tarafdar, J. Effect of Banana Bunchy Top Virus on the Heat Shock Protein Genes of Pentalonia nigronervosa during Temperature Susceptibility and Its Effect on Virus Transmission. Agronomy 2021, 11, 1866. https:// doi.org/10.3390/agronomy11091866

Academic Editor: Adi Kliot

Received: 3 June 2021

Accepted: 8 July 2021

Published: 17 September 2021

Publisher's Note: MDPI stays neutral with regard to jurisdictional claims in published maps and institutional affiliations.

Copyright: (c) 2021 by the authors. Licensee MDPI, Basel, Switzerland. This article is an open access article distributed under the terms and conditions of the Creative Commons Attribution (CC BY) license (https:// creativecommons.org/licenses/by/ $4.0 /)$.

\begin{abstract}
Acquisition of plant viruses is known to exert various effects on vectors' developmental biology. Pentalonia nigronervosa is the only known vector of banana bunchy top virus (BBTV), which is an economically detrimental virus infecting banana cultivars all over the world. In the present study, the developmental biology of viruliferous (Vr) and non-viruliferous (NVr) aphids was compared, with a marked reduction noted in the lifespan of aphids upon acquisition of BBTV. Among all the environmental parameters temperature is an important determinant of an insect's abundance and geographical distribution. Temperature susceptibility of $P$. nigronervos $a$ was scrutinized by comparing the mortality percentage and differential expression pattern of three heat shock proteins (Hsps; Hsp40, Hsp70, and Hsp90) at the mRNA level between $\mathrm{NVr}$ and $\mathrm{Vr}$ aphids. After exposure to different temperature stress $\left(5^{\circ} \mathrm{C}, 15^{\circ} \mathrm{C}, 38^{\circ} \mathrm{C}\right.$ and $25^{\circ} \mathrm{C}$ as control) highest mortality of $\mathrm{Vr}$ aphids were recorded at $5{ }^{\circ} \mathrm{C}$. Analysis of expression levels of Hsp genes using qPCR showed that both cold and heat shock treatment stimulated higher expression of the three Hsps at various rates in $\mathrm{Vr}$ than $\mathrm{NVr}$ aphids.. Finally, the effect of temperature stress on the BBTV titer level and their transmission by P.nigronervosa was determined by absolute quantification. The transmission efficiency along with the virus titer was found to be the lowest at $15{ }^{\circ} \mathrm{C}$ compared to $38^{\circ} \mathrm{C}$. Overall, our results provide a novel insight into the intricate interaction between aphid fitness and thermal stress concerning the acquisition and transmission of BBTV, which could be a roadmap for the future epidemiological control system.
\end{abstract}

Keywords: BBTV; vector; transmission; aphid fitness; viruliferous; virus titre; real-time PCR

\section{Introduction}

There are bounteous probabilities for the herbivorous insects and plant pathogens interacting with each other while occurring on the same host plant [1]. Such interactions are based on direct competition between the insect and the pathogen for plant nutrients [2-5]. The interactions are further complicated if the pathogens depend on the vectors for their transmission to new host plants. Such an intricate relationship between plant-pathogenvector systems is still an ambiguous mechanism to delineate. Arthropod vectors, including insects, transmit about $70 \%$ of the plant-infecting viruses [6], with aphids alone transmitting $50 \%$ of the known viruses [7]. The viruses depending on their vector ultimately alter the vector's developmental biology, fecundity, and overall fitness. This connotation between the vector and its pathogen may be positive [8], negative, or neutral [9]. A positive effect on a vector is mediated through various plant-directed interactions such as the attraction of aphids towards virus-infected yellow leaves due to visual stimuli or olfactory stimuli 
or by the production of volatile compounds $[4,10,11]$. Virus acquisition may also facilitate negative or neutral modification in developmental biology and fecundity of vectors [4]. Thrips (Frankliniella occidentalis) carrying tomato spotted wilt virus (TSWV) is one such example that showed decreased rates of reproduction and survivability [12]. The complex interactions among viruses, vectors, and plants in the context of the virulence transmission trade-off hypothesis for vector-borne plant viruses have been explicitly explained [13]. However, the physiological and molecular changes that the vector undergoes on the acquisition of a virus have been unequivocally stated only in certain insects such as whitefly [14].

The interaction between virus and vector is greatly dependent on environmental factors [15]. Among these factors, temperature is an important determinant of the vectors biology and their transmission efficiency [16] and is one of the most important climatic parameters that can influence virus transmission. Thermal stress has been demonstrated to play a significant role in regulating vector susceptibility, i.e., altering vectors' capability to mediate virus transmission in insects such as whitefly [17]. However, the exact mechanism by which such alteration occurs is still unclear. During the course of evolution, insects have adopted many strategies to avoid temperature impairments, such as seeking shelter and accumulating sugars, proteins, and amino acids [18-20]. One such physiological adaptation at the molecular level, which is of prime importance, is the expression of heat shock proteins (Hsps). Heat shock proteins (Hsps) are products of different biotic and abiotic stress conditions [21]. Based on the molecular weight, heat shock proteins are primarily divided into several families, including Hsp100, Hsp90, Hsp70, Hsp60, Hsp40, and small Hsps [22-24]. They act as molecular chaperones enabling the folding, transport, and assembly of disintegrated proteins [24].However, one of the most fascinating and lesser-known aspects is the effect of virus infection on heat shock response (HSR) [25].

The Banana Bunchy Top Virus (BBTV; Genus Babuvirus; Family Nanoviridae) is one of the major destructive viruses causing limited production in banana [26]. It is a positive sense $(+)$ circular single-stranded (ss) multipartite DNA virus with six genome components of $1.1 \mathrm{~kb}$ each $[27,28]$. Each of the genomes have single Open Reading Frame (ORF), where DNA-C encodes a cell cycle link protein, DNA-M encodes a movement protein, DNA-R encodes replication initiation protein, DNA-S encodes capsid protein (CP), DNA-N encodes a nuclear shuttle protein, and the function of the DNA-U3 is not yet known [29]. A highly conserved major common region (CR-M) and a stem-loop common region (CR-SL) are observed in all the six segments [28]. The only known vector of BBTV is banana black aphid, Pentalonia nigronervosa (Family Aphididae; Order Hemiptera) which transmits the virus in a persistent, circulative and non-propagative manner. BBTV is economically destructive and is enlisted among the top world's worst invasive alien species [30]. There have been reports highlighting the rate of acquisition and transmission of BBTV by the black aphid [31]. Nonetheless, the influence of temperature susceptibility in banana aphid upon acquisition of BBTV is relatively unexplored despite studies being carried out in other hemipteran insects, such as whitefly (Bemisia tabaci) [32].

Keeping the above facts in mind, the goal of our present experiment was to find the relationship between the BBTV and its associated vector $P$. nigronervosa in relation to temperature stress conditions. The following aspects have been highlighted: (i) the differences between the life cycles of viruliferous ( $\mathrm{Vr}$ ) and non-viruliferous ( $\mathrm{NVr}$ ) aphids; (ii) the effect of temperature stress on the mortality rate of both $\mathrm{Vr}$ and $\mathrm{NVr}$ adult aphids along with the change in the relative expression of three Hsp (Hsp40, Hsp70, and Hsp90) genes at the molecular level; (iii) lastly, an important factor that has also been addressed is the effect of thermal stress on BBTV concentration and its effect on the transmission rate of the virus to healthy banana plants of cv. Grand Naine. Precisely, certain key research priorities have been discussed that give a deeper insight into how abiotic stress (temperature) influences the viral transmission efficiency of the aphid vector (Pentalonia nigronervosa). To our knowledge, the present experiment can be considered an important step in drawing attention towards the effect of the temperature stress response 
of Pentalonia nigronervosa in the context of virus acquisition and effect of temperature stress on virus transmission, further highlighting its importance in epidemiological control of BBTV.

\section{Materials and Methods}

\subsection{Sample Collection and Insect Rearing}

Adult apterous aphids of $P$. nigronervosa were initially collected from a healthy field at a Mandauri farm, BCKV, in 2019.The collected aphids were tested BBTV negative and reared for 30-40 generations at the Directorate of Research Laboratory at Kalyani $\left(22.9747^{\circ} \mathrm{N}\right.$, $88.4337^{\circ} \mathrm{E}$ ), Nadia district, West Bengal. The insects were transferred to 60-day-old virusfree certified tissue culture (TC) banana plants of cv. Grand Naine in an insect-proof cage $(40 \times 60 \times 60 \mathrm{~cm})$ and were maintained as NVr colonies. A portion of NVr aphids was collected and transferred to a different insect cage and fed on BBTV-infected banana plants of cv. Grand Naine and thus maintained as Vr colonies. Insect rearing was conducted under controlled environmental conditions at $25 \pm 1{ }^{\circ} \mathrm{C}$ with $60-80 \% \mathrm{RH}$ and $16 \mathrm{~h}$ light/ $8 \mathrm{~h}$ dark conditions. BBTV-positive plants were confirmed by polymerase chain reaction (PCR)protocol [33], following which Vr aphids were confirmed from time to time after the experiment by using coat protein specific primer (DNA-S). All the full-length complete genomes were isolated, characterized, sequenced, and submitted to the NCBI database with accession numbers MW241552, MT670274, MW241551, MW241550, MW241549, and MT109277 for DNA-S, DNA-C, DNA-M, DNA-N, DNA-R, and DNA-U3, respectively.

\subsection{Observation of Developmental Stages}

To analyze the developmental parameters of NVr and Vr adult aphids, 30-40 aphid colonies were collected from the insect cage and placed onto leaves of new banana plants (60-day-old TC plants) in a different insect-proof cage box and enclosed in clip cages ( $3 \mathrm{~cm}$ diameter). Three clip cages (replicates) were attached to the leaves and each clip cage consisted of 10 aphids. Aphids were kept overnight to produce the nymphs. The adult aphids were removed, and the first-generation nymphs of same size laid overnight by the aphids were selected to examine the lifecycle and developmental stages.

\subsection{Thermal Stress on Pentalonia nigronervosa}

Second-generation one-day-old apterous adult aphid colonies of both $\mathrm{NVr}$ and $\mathrm{Vr}$ developed from the first-generation nymphs were selected and kept in separate small glass tubes $(10 \mathrm{~mL})$ consisting of 20 aphids in each glass tube. The opening of the glass tube was covered with a gauge at the top for smooth breathing and for maintaining a uniform temperature. Then, the aphids were incubated in different temperature treatments $\left(\mathrm{T} 1>5{ }^{\circ} \mathrm{C}, \mathrm{T} 2>15{ }^{\circ} \mathrm{C}, \mathrm{T} 3>38{ }^{\circ} \mathrm{C}\right.$, and $\mathrm{C}>25{ }^{\circ} \mathrm{C}$ ) in a MERCK incubator for $3 \mathrm{~h}, 25^{\circ} \mathrm{C}$ being the control for the experiment. Later, the tubes were transferred to $25^{\circ} \mathrm{C}$ to allow the adult aphids to recover for $1 \mathrm{~h}$. Each treatment comprised three replicates with 20 adult apterous insects in each replicate. The mortality rate of the apterous adults in each replicate was calculated by counting the number of dead and live adults.

\subsection{Quantitative Real-Time PCR ( $q P C R)$ Analysis}

Heat shock-treated NVr and Vr aphid samples (20 individuals/treatment) were subjected to RNA extraction with the help of an insect RNA extraction kit (Thermo Fisher Scientific). The quantity and quality of purified RNA were validated using a Nano Drop 1000 spectrophotometer. Synthesis of complementary DNA (cDNA) was performed using a Gene Sure H-Minus First Strand cDNA Synthesis Kit (Gene tix Biotech Asia Pvt. Ltd., New Delhi, India). Gene-specific primers for Hsp40, Hsp70, and Hsp90 were designed using nucleotide sequences from the NCBI database (Table 1). The expressions of Hsp genes in both Vr and NVr aphids were examined by relative quantification using qRT-PCR protocol along with 2X SYBR Green qPCR Master Mix (Applied Biosystems and KAPA Biosystems, Wilmington, MA, USA). The cDNA samples were run in triplicate to ensure the 
validity of the data using the Agilent Technologies Stratagene Mx3000P Sequence Detection System. Amplification was carried out in $10 \mu \mathrm{L}$ reaction containing $5 \mu \mathrm{L} 2 \mathrm{X}$ SYBR Green PCR Master Mix, $0.5 \mu \mathrm{L}$ of each primer $(10 \mu \mathrm{M}$ each), $1 \mu \mathrm{L}$ template DNA, $0.2 \mu \mathrm{L}$ ROX, and $2.8 \mu \mathrm{L}$ molecular grade water. The standard amplification profile was $95^{\circ} \mathrm{C}$ for $4 \mathrm{~min}$ followed by 40 cycles of $95{ }^{\circ} \mathrm{C}$ for $40 \mathrm{~s}$ and $60^{\circ} \mathrm{C}$ for $40 \mathrm{~s}$, and $45 \mathrm{~s}$ at $72{ }^{\circ} \mathrm{C}$, and followed by a melt curve analysis, which was performed by allowing the reactions at $95^{\circ} \mathrm{C}$ for $15 \mathrm{~s}$, $60{ }^{\circ} \mathrm{C}$ for $30 \mathrm{~s}$, and $95^{\circ} \mathrm{C}$ for $15 \mathrm{~s}$. The relative expression of each target gene was calculated with the $2^{-\Delta \Delta \mathrm{Ct}}$ method [14]. The $\beta$-actin (nuclear gene) level, which did not reflect any significant difference across treatments, was used as a reference [34].

Table 1. Sequences of the designed primers for the coat protein gene of BBTV and Hsp genes of P. nigronervosa.

\begin{tabular}{cccc}
\hline Serial No. & Gene & Primer Sequence & Product Size ( ) \\
\hline 1 & $\begin{array}{c}\text { DNA-S } \\
\text { (q-PCR) }\end{array}$ & $\begin{array}{c}\text { F-5'GCTTCTTGTGTGCAAGGTGA'3 } \\
\text { R-5'CCTCAACACGGTTGTCTTCC'3 }\end{array}$ & 226 \\
\hline 2 & Hsp40 & $\begin{array}{c}\text { F-5'GGGAAATGTCCGTCAAAGAA'3 } \\
\text { R-5'GAGTTTCATGGTGTCGCCTA'3 }\end{array}$ & 206 \\
\hline 3 & Hsp70 & $\begin{array}{c}\text { F-5'TCTTTCCTCATCCACCCAAG'3 } \\
\text { R-5'ACAATGTCGTTGATGGCAGA'3 }\end{array}$ & 186 \\
\hline \multirow{2}{*}{4} & Hsp90 & $\begin{array}{l}\text { F-5'TCCCTGTTGCATTGTCACAT'3 } \\
\text { R-5'TTGTCGTTGCAATCAGCTTC'3 }\end{array}$ & 186 \\
\hline
\end{tabular}

\subsection{Effect of Temperature Stress on Transmission of BBTV}

To determine the effect of temperature stress on the transmission of BBTV, an experiment was conducted where 50 adult aphids were transferred to each clip cage of 10 infected plants per treatment with a $24 \mathrm{~h}$ Acquisition Access Period(AAP). They were kept at three different temperatures, $15^{\circ} \mathrm{C}, 38^{\circ} \mathrm{C}$, and $25^{\circ} \mathrm{C}$, where $25^{\circ} \mathrm{C}$ was used as a control temperature. Transmission at $5{ }^{\circ} \mathrm{C}$ was not taken into consideration because it was impossible for the aphid to survive at such a low temperature. After AAP, the aphids were individually transferred at room temperature and then returned to their respective temperatures at $24 \mathrm{~h}$ Inoculation Access Period (IAP). After $24 \mathrm{~h}$ of transmission, the banana plants were sprayed with $0.02 \%$ imidacloprid (Confidor, Bayer) to kill the aphids. Progression of the symptoms was monitored regularly until symptom expression for about 75 days.

\subsection{Preparation of Standard DNA Templates for Standard Curve Construction}

Total DNA was isolated from the test banana samples using a plant DNA extraction kit (Thermo Fisher Scientific).The quantity and quality of the DNA were determined using a Nano Drop 1000 spectrophotometer (Thermo Fisher Scientific, Wilmington, DE, USA).For the absolute quantification of the virus, a standard curve was generated using a partial coat protein gene of about $226 \mathrm{bp}$ size, which was designed from our submitted DNA-S full genome sequence using Primer3 Input (version 0.4.0; Table 1). The amplified gene was then cloned into the pGEM-T Easy vector (Promega Corp., Fitchburg, MA, USA) and used as a template in qPCR using SYBR green chemistry. The plasmid was then purified and quantified $(\mathrm{ng} / \mu \mathrm{L})$ and was serially diluted to a10-fold five-point dilution series. The copy number of the DNA in each dilution was calculated [35]. The default settings of the Mx3000P qPCR software on the qPCR system were used for data acquisition and processing.

\subsection{Absolute Quantification of the Viral Titer through qRT-PCR Assay}

Absolute quantification of the BBTV titer in aphid and test plant leaf samples was performed by qRT-PCR. Amplification reaction was triplicated and carried out in $10 \mu \mathrm{L}$ reaction containing the reaction mixture as previously stated. The reaction was required 
for 1 cycle of denaturation $\left(95^{\circ} \mathrm{C}\right.$ for $\left.3 \mathrm{~min}\right), 40$ cycles of elongation $\left(95^{\circ} \mathrm{C}\right.$ for $40 \mathrm{~s} ; 60^{\circ} \mathrm{C}$ for $40 \mathrm{~s} ; 72{ }^{\circ} \mathrm{C}$ for $\left.45 \mathrm{~s}\right)$, and 1 cycle of dissociation $\left(95^{\circ} \mathrm{C}\right.$ for $15 \mathrm{~s} ; 60^{\circ} \mathrm{C}$ for $30 \mathrm{~s} ; 95^{\circ} \mathrm{C}$ for $15 \mathrm{~s}$ ).

\subsection{Statistical Analysis}

All percentage data were arcsine square root transformed for use in statistical analysis. Statistical data analysis with the mean values \pm standard error was computed in the RStudio (R version 3.4.3) [36]. One-way analysis of variance (ANOVA) and Tukey test using a general linear model, and bivariate correlation analysis were performed using Agricolae R package [37], and independent-sample Student $t$-test was performed using tidyverse R package [38] with readxl (version 1.0.0) as default settings. The developmental stages were compared using ANOVA followed by Tukey test at $p<0.05$. Comparisons of the survival of adult aphids at different temperature treatments were performed by using independent-sample Student $t$-test. The differences in the relative expression of Hsp genes of Vr and NVr aphids treated under different temperature stress conditions were analyzed using independent-sample Student $t$-test. The differences between treatments were considered significant when $p<0.05$. The relationship between two variables, i.e., threshold cycle (CT) and virus copy number, was statistically determined using bivariate correlation analysis (Pearson correlation coefficients and two-tailed test of significance).

\section{Results}

\subsection{Comparison of the Lifespans of Non-Viruliferous and Viruliferous P. nigronervosa}

During the course of the investigation, it was found that the nymphs passed through four instar stages to become adult and the total lifespan during the first generation was 35.66 and 48.33 days for Vr and NVr aphids, respectively. The overall nymphal duration for Vr was found to be 3 days shorter than the NVr ones, whereas the developmental duration between each stage slightly differed. In addition, the Vr adult aphids during the first generation were 9.66 days shorter than the NVr ones. Hence, the overall lifespan of Vr aphids during the first generation of the aphids was 12.66 days shorter than the $\mathrm{NVr}$ ones (Table 2).

Table 2. Comparison of the developmental period of each stage of NVr and Vr P. nigronervosa.

\begin{tabular}{|c|c|c|c|c|}
\hline \multicolumn{2}{|c|}{ Development Stage } & \multicolumn{2}{|c|}{ Development Periods (Days) } & \multirow{2}{*}{$\begin{array}{c}\text { Difference of Mean (Days) } \\
\text { (NVr-Vr) }\end{array}$} \\
\hline & mph & $\begin{array}{l}\text { Viruliferous (Vr) } \\
\quad \pm \mathrm{SE}\end{array}$ & $\begin{array}{c}\text { Non-Viruliferous (NVr) } \\
\pm \mathrm{SE}\end{array}$ & \\
\hline & Instar 1 & $2.333 \pm 0.333^{a}$ & $3 \pm 0^{b}$ & 0.6667 \\
\hline & Instar 2 & $2.666 \pm 0.333^{a}$ & $3.6667 \pm 0.333^{b}$ & 1.001 \\
\hline & Instar 3 & $2.33 \pm 0.333^{a}$ & $3.3333 \pm 0.333^{b}$ & 1 \\
\hline & Instar 4 & $2.667 \pm 0.333^{\mathrm{a}}$ & $3 \pm 0.577^{\mathrm{a}}$ & 0.3333 \\
\hline Adult & Apterous Aphid & $25.667 \pm 0.667^{\mathrm{a}}$ & $35.333 \pm 0.333^{b}$ & 9.666 \\
\hline Total & & $35.66667^{a}$ & $48.33333^{b}$ & 12.663 \\
\hline
\end{tabular}

In the same row, the means followed by the same letters are not significantly different at $p<0.05$ level; SE denotes standard error.

\subsection{Effects of Temperature Stress on Adult Mortality}

To evaluate the direct effect of temperature stress in both the aphids, the mortality rate of the adults was calculated after $30 \mathrm{~min}$ of exposure to thermal stress up until $3 \mathrm{~h}$ (Figure 1). A $3 \mathrm{~h}$ exposure to $5{ }^{\circ} \mathrm{C}$ resulted in initial mortality percentages of $41.69 \%$ (NVr) and $43.85 \%(\mathrm{Vr})$, which gradually increased to around $90 \%$ for both the aphids after cold shock (Figure 1A).The mortality percentage was significantly lowered when the aphid populations were treated at $15{ }^{\circ} \mathrm{C}$, showing initial mortality of about $4.62 \%$ for $\mathrm{NVr}$ aphids and $10.49 \%$ for $\mathrm{Vr}$ aphids, which finally led to $11.53 \%$ mortality, which is comparatively lower than $17.78 \%$ mortality for $\operatorname{Vr}$ (Figure 1B). With an increase in thermal stress, i.e., at $38^{\circ} \mathrm{C}$, a similar kind of mortality percentage was observed, with an initial mortality percentage of $8.13 \%$ for NVr aphids and 
$16.41 \%$ for $\mathrm{Vr}$ aphids. The aphid population was finally reduced after $3 \mathrm{~h}$ exposure, with a mortality percentage of $18.74 \%$ for NVr aphids and $26.32 \%$ for Vr aphids (Figure 1C).

Cold shock at $5^{\circ} \mathrm{C}$

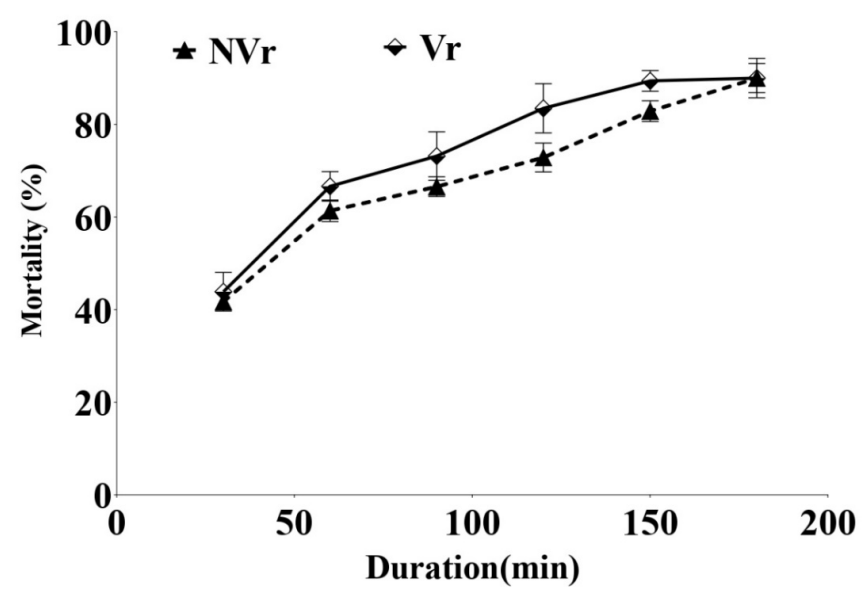

(A)

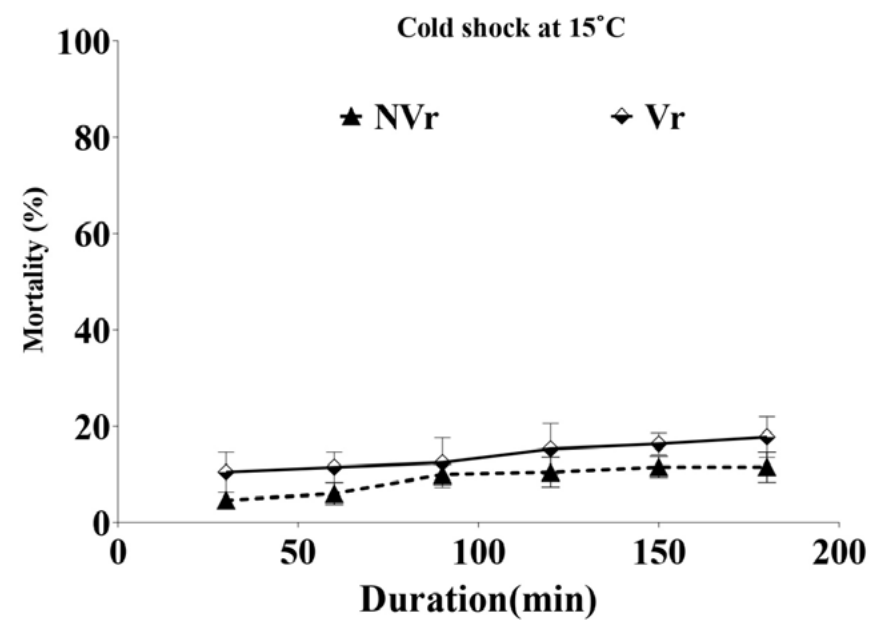

(B)

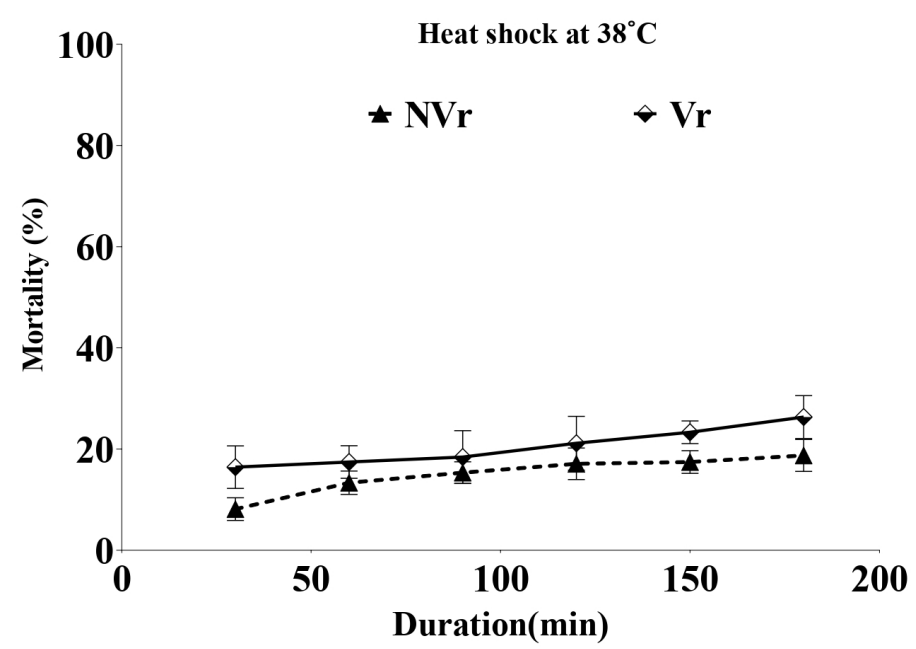

(C)

Figure 1. Mortality percentage of adult apterous $\mathrm{Vr}$ and $\mathrm{NVr}$ aphids at different temperature stress. (A) Mortality percentage at $5^{\circ} \mathrm{C}$. (B) Mortality percentage at $15^{\circ} \mathrm{C}$. (C) Mortality percentage at $38^{\circ} \mathrm{C}$. The total number of samples taken were considered as $100 \%$. Bars represent the standard error of the mean (SEM). 


\subsection{Effect of Temperature Stress on the Expression of Heat Shock Protein Genes}

Treatment of $\mathrm{Vr}$ and $\mathrm{NVr}$ aphids with different temperatures $\left(5^{\circ} \mathrm{C}, 15^{\circ} \mathrm{C}, 38^{\circ} \mathrm{C}\right.$, and $25^{\circ} \mathrm{C}$ acting as the control) resulted in varying changes in the transcript level of Hsps (Figure 2). At the control temperature of $25^{\circ} \mathrm{C}$, the transcript levels of three Hsps did not differ significantly ( $p>0.05$ in all the genes) between $\mathrm{Vr}$ and $\mathrm{NVr}$ aphids. Following cold temperature treatment $\left(5^{\circ} \mathrm{C}\right)$, the transcript levels of Hsp40 (Figure 2A), Hsp70 (Figure 2B), and Hsp90 (Figure 2C) were significantly ( $p<0.05$ in all the genes) upregulated in $\mathrm{Vr}$ aphid as compared to $\mathrm{NVr}$ aphids. The ratios of $\mathrm{Vr}$ to $\mathrm{NVr}$ aphids in terms of transcript levels of Hsp40, Hsp70, and Hsp90 were $3.29,3.31$, and 3.29 , respectively. Temperature treatment at $15^{\circ} \mathrm{C}$ resulted in insignificantly $(p<0.05$ in all the genes) higher transcript levels of the three Hsps in Vraphids compared to $\mathrm{NVr}$ aphids. The ratios of $\mathrm{Vr}$ to $\mathrm{NVr}$ aphids in terms of transcript levels of Hsp40, Hsp70, and Hsp90 were 1.76, 6.29, and 6.40, respectively. Similarly, heat shock treatment $\left(38^{\circ} \mathrm{C}\right)$ also resulted in higher transcript levels of Hsp40, Hsp70, and Hsp90 $(p<0.05$ in all the genes) in $\mathrm{Vr}$ aphids compared to $\mathrm{NVr}$ aphids. The ratios of $\mathrm{Vr}$ to $\mathrm{NVr}$ aphids were 3.77, 2.63, and 2.65 , respectively.

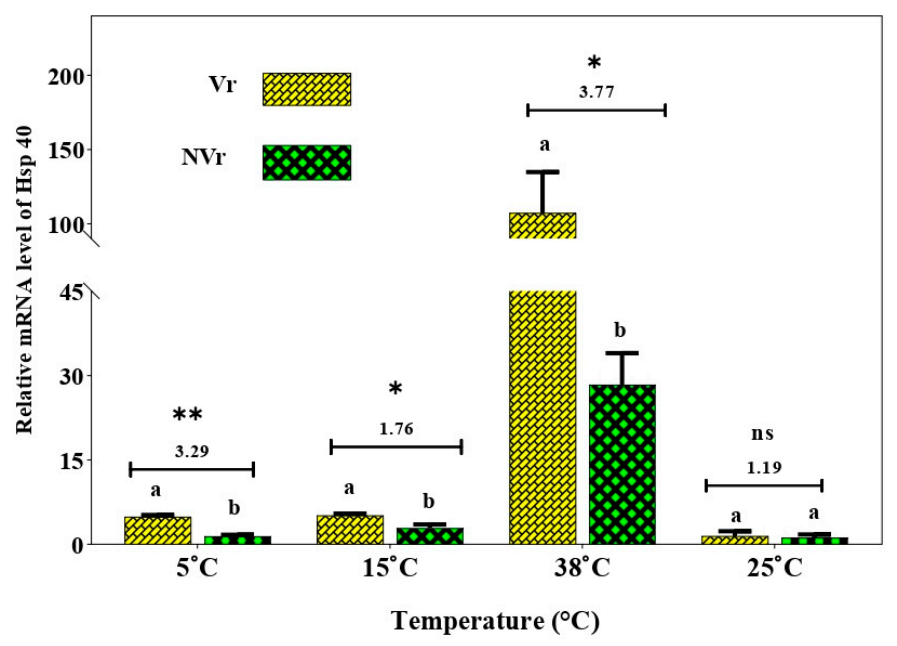

(A)

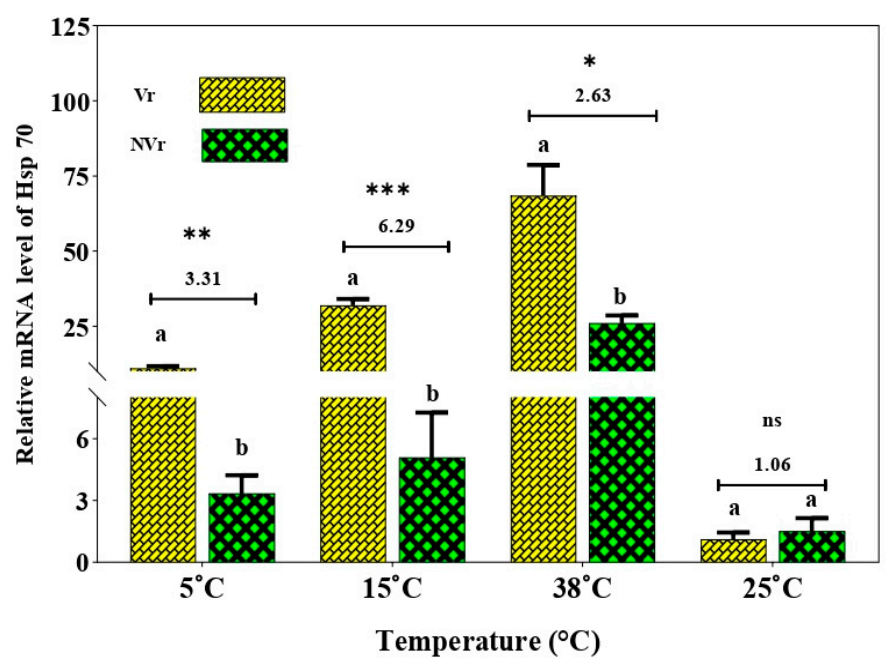

(B)

Figure 2. Cont. 


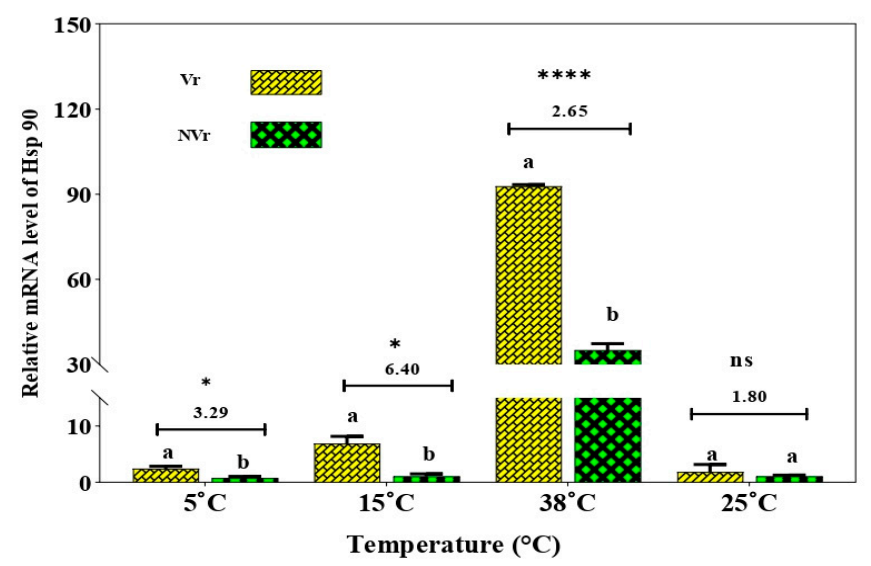

(C)

Figure 2. The differential expression of Hsp genes on exposure to different values of temperature stress $\left(5^{\circ} \mathrm{C}, 15^{\circ} \mathrm{C}\right.$, and $\left.38^{\circ} \mathrm{C}\right)$. (A) Hsp 40, (B) Hsp 70, and (C) Hsp 90.The bars represent the standard error of the mean (SEM), and the different letters above the symbols indicate a significant difference at 0.05 level; "ns" indicates that there is no significant difference between the two means at a given temperature; ${ }^{*}$ indicates significant difference between the two means at a given temperature $(p<0.05) ; * *$ indicates significant difference between the two means at a given temperature $(p<0.01) ;{ }^{* * *}$ indicates significant difference between the two means at a given temperature $(p<0.001) ; * * * *$ indicates significant difference between the two means at a given temperature $(p<0.0001)$.

\subsection{Effect of Temperature Stress on Virus Transmission}

Temperature was found to play a substantial role in the transmission of the BBTV by Pentalonia nigronervosa where the time taken to express the symptoms significantly varied at these temperatures. After $24 \mathrm{~h}$ of AAP, the viral load in aphids was noted to be maximum at $25{ }^{\circ} \mathrm{C}$, with the highest BBTV copies/ng showing the maximum transmission rate $(100 \%)$ with visible symptom expression by about 35.32 days. The BBTV titer in the aphids at $38{ }^{\circ} \mathrm{C}$ was very low compared to that at $25^{\circ} \mathrm{C}$ with low transmission rate, and symptom expression was delayed and not noticeable within 75 days of observation, but was observed after around 97.1 days. Although the virus titer at $15{ }^{\circ} \mathrm{C}$ was much less, with very few copy numbers/ng, virus transmission was possible with a low transmission efficiency, showing visible symptom expression not within 75 days of observation but after around 189.21 days of inoculation (Table 3, Figure 3).

Table 3. Absolute quantification of BBTV titer in aphids through the SYBR Green-based qPCR assay for various temperature treatments. SE denotes standard error.

\begin{tabular}{cccccc}
\hline S1. No. & $\begin{array}{c}\text { Temperature } \\
\left({ }^{\circ} \mathbf{C}\right)\end{array}$ & $\begin{array}{c}\text { Virus Titer } \\
\text { (Viral Copies } \pm \text { SE) }\end{array}$ & $\begin{array}{c}\text { CT (Threshold Cycle) } \\
(\text { Mean } \pm \text { SE) }\end{array}$ & $\begin{array}{c}\text { BBTD Incidence } \\
\text { (\%) }\end{array}$ & $\begin{array}{c}\text { Time Taken for BBTD } \\
\text { Symptom Expression } \\
\text { (Days) (Mean } \pm \text { SE) }\end{array}$ \\
\hline 1 & 15 & $12.34 \pm 0.27$ & $28.32 \pm 0.566$ & 50 & $189.21 \pm 9.19$ \\
\hline 2 & 25 & $116,203.91 \pm 1244.40$ & $15.21 \pm 0.566$ & 100 & $35.32 \pm 8.73$ \\
\hline 3 & 38 & $371.20 \pm 6.97$ & $23.44+0.536$ & 70 & $97.1 \pm 7.55$ \\
\hline
\end{tabular}




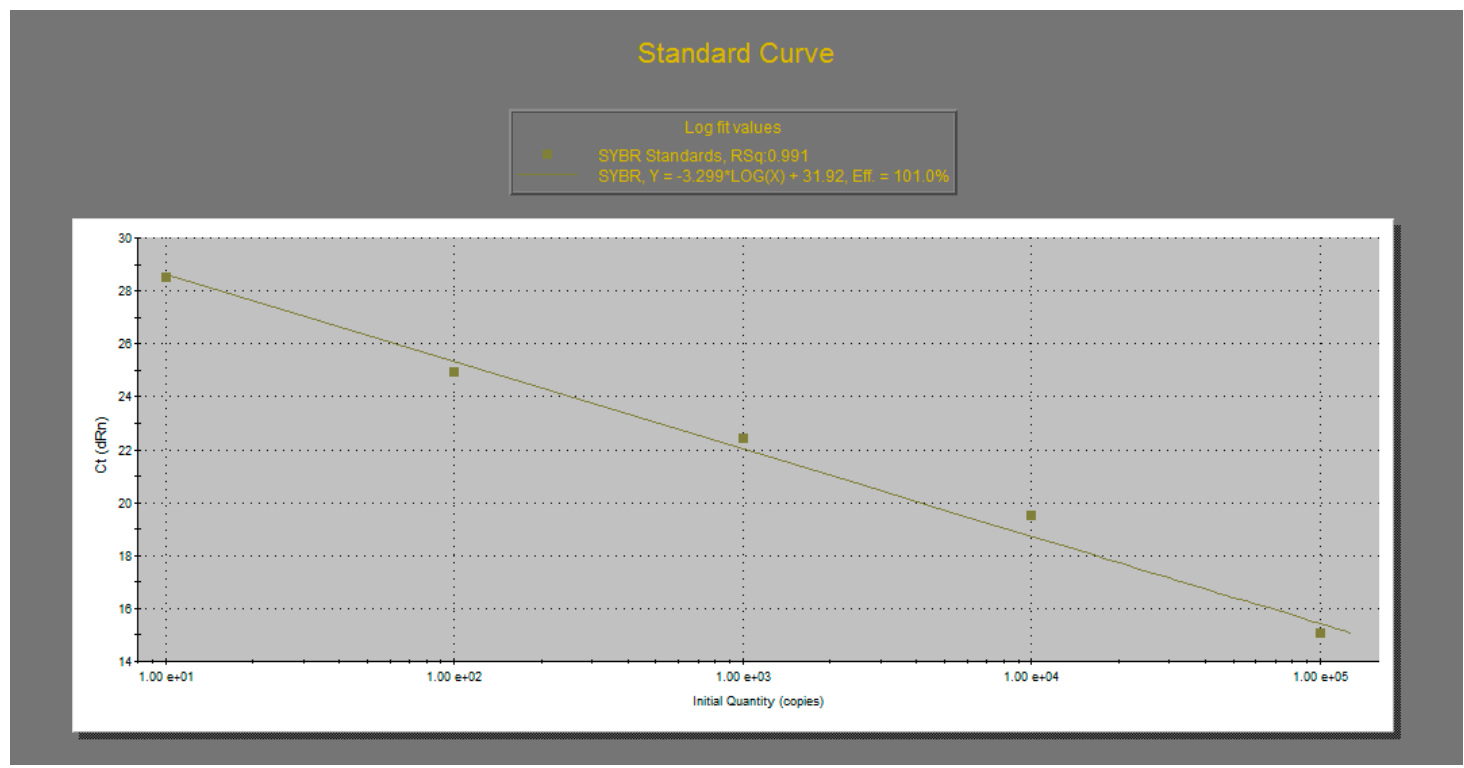

(A)

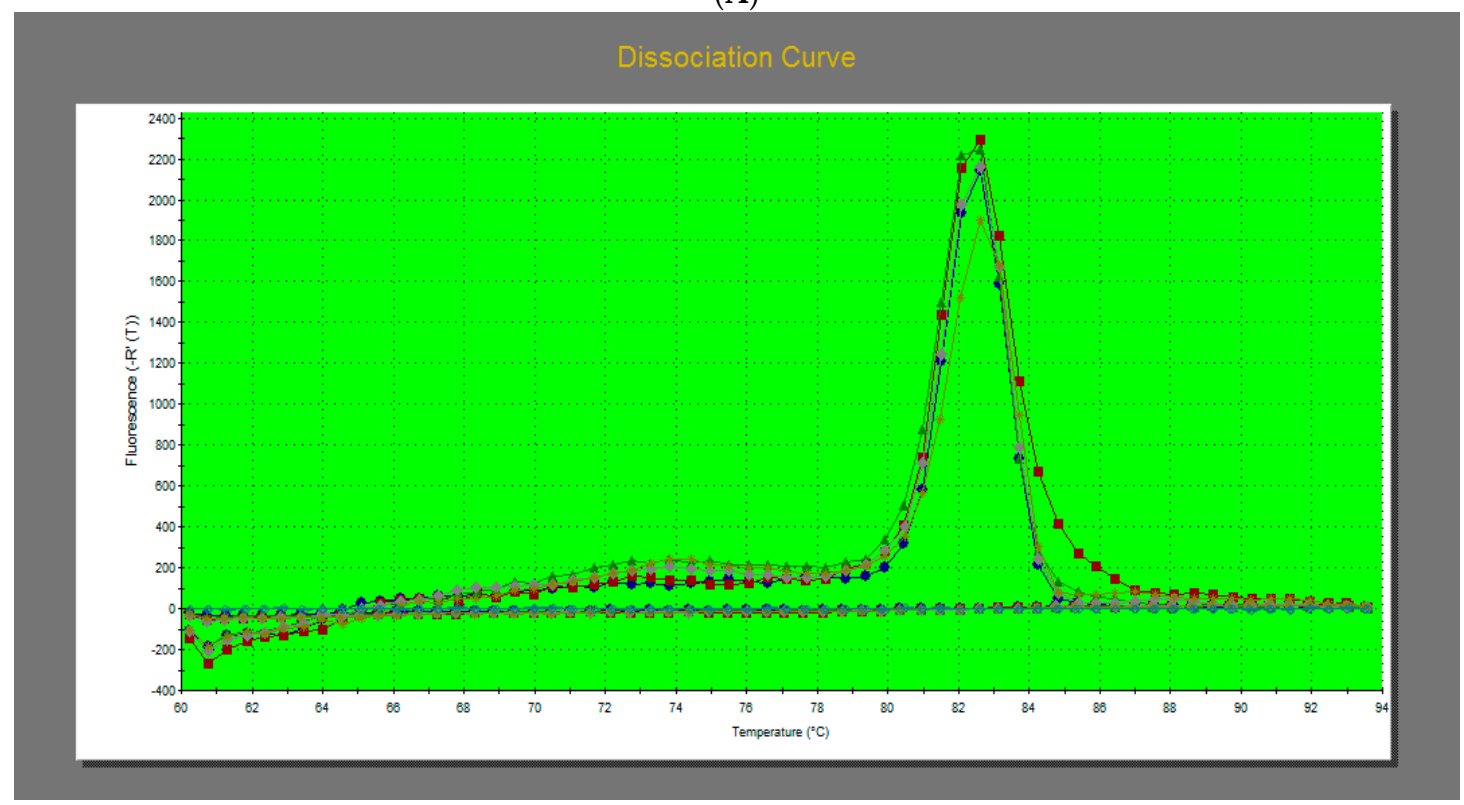

(B)

Figure 3. (A) Standard curve generated from the Mx3000P qPCR software based on virus copies from the plasmid BBTV-CP-pGEM-T Easy vector versus the number of cycles that were required to reach CT. The regression equation is $\mathrm{CT}=-3.299 * \log$ (number of virus copy) $+31.92\left({ }^{* * \prime}\right.$ denotes multiplication sign). Amplification efficiency is $101.0 \%$ and the coefficient of determination $\left(\mathrm{R}^{2}\right)$ is greater than 0.99 , which is acceptable. (B) Melt peak chart showing the melt profile for qPCR amplicons of the coat protein gene of BBTV from all test samples. The flat line indicates the negative control that failed to amplify.

\section{Discussion}

The results of our experiment reflected how temperature stress influences virus acquisition that has a consequential effect on aphid developmental biology. Upon BBTV acquisition, there was a significant shortage in the developmental period of aphids, leading to a reduction in their lifespan. However, the changes were more significant in the adult longevity period in comparison with the nymphal stages. Previously, alterations of the physiological growth in the vector by their vector-borne pathogens were reported in aphids transmitting bean yellow mosaic virus (BYMV), and broad bean mottle virus (BBMV). Nonetheless, no change was noticed in the survival and growth of pea aphids transmitting 
pea enation mosaic virus (PEMV) [4]. There are several earlier lines of evidence indicating that the acquisition of viruses such as tomato yellow leaf curl virus (TYLCV) [39], squash leaf curl virus (SqLCV), and cotton leaf curl virus $(\mathrm{CLCuV})$ [32] reduced the physiological growth stages of the insect vector whitefly. Moreover, virus acquisition can also alter other physiological functions such as feeding behavior in thrips [12]. Some literature further suggested that the stimulation of metabolic upregulation results in such behavioral response, which further justifies the reason for such shortening of developmental stages in banana aphids [14]. Another interesting mechanism may be the Hsps-mediated shuttling of the infective viral particles from insect midgut cells to the hemolymph, which helps in minimizing virus contact with insect tissue [40].

However, developmental variations in Pentalonia species can be caused by cultivar differences, genotypic variation, and agro-ecological variation, which has already been justified [41]. Again, BBTV transmission and its insect developmental biology are highly correlated and found to be congenial at around 25 to $27^{\circ} \mathrm{C}$ [42]. Keeping in view all the external parameters that may influence the results, the experimented host plants were thus maintained under homogeneous conditions and climate-controlled chambers. Nevertheless, the fact that plant conditions may affect the developmental biology of the insect cannot be completely ruled out; hence, further analysis is required based on an artificial diet provided with cloned virions.

Thermal tolerance is a critical parameter for the establishment or spread of any insect species [43]. Temperature susceptibility has been reported to vary according to biotype and geography in insects such as whitefly [14]. Keeping this in mind, we determined the mortality percentage of adult $P$. nigronervosa (both $\mathrm{Vr}$ and $\mathrm{NVr}$ aphids) on exposure to thermal stress, highlighting the molecular aspects underlying the heat-responsive mechanism in banana black aphids. Our results showed that thermal tolerance of adult aphids reduces considerably upon acquisition of BBTV, with an increased mortality percentage of $\mathrm{Vr}$ aphids compared to $\mathrm{NVr}$ ones. The exact mechanism of this thermal weakening is still unclear, and further research is required to elucidate the mechanisms by which BBTV alters aphid gene expression. However, the increased mortality of $\mathrm{Vr}$ aphids may be due to the deleterious effects of BBTV on P. nigronervosa. Moreover, exposure to cold shock resulted in increased mortality percentage of both $\mathrm{Vr}$ and $\mathrm{NVr}$ aphids compared to heat shock treatment. A possible reason for this variation may be differential expression patterns of Hsps, which are responsible for the repair and degradation of proteins destroyed due to thermal stress [44].We are well aware of heat shock proteins (Hsps) and their role in heat/cold adaptations, metamorphosis, and other critical functions in insects [45,46]. Attention has been drawn towards the role of Hsps in thermal tolerance in several insects, including aphids [47]. Reports also indicated alterations in several Hsps in B.tabaci under thermal stress conditions $\left(40^{\circ} \mathrm{C}\right.$ or $\left.44^{\circ} \mathrm{C}\right)$ [48]. However, several contradictory reports have been addressed where thermal tolerance in Rhopalosiphum padi appears to increase with the acquisition of barley yellow dwarf virus (BYDV), leading to an expansion of the thermal niche of the vector [49]. It has also been reported in Southern rice black-streaked dwarf virus, which increases heat tolerance in its vector, Sogatella furcifera [50]. Nonetheless, an important aspect that remains unattended is the response of Hsp genes in P. Nigronervosa to thermal stress. Our results displayed significant changes between $\mathrm{Vr}$ and NVr aphids in response to thermal stress. Upon exposure to both heat and cold stress, the transcript level of all the three Hsps (Hsp40, Hsp70, and Hsp90) was significantly higher in Vr aphids in comparison with $\mathrm{NVr}$ aphids. Hence, these results are suggestive of the fact that acquisition of BBTV virus might have some role to play in increased transcript level of the three Hsps under temperature stress conditions in P.nigronervosa. Interestingly, no significant difference in Hsp transcript level was noted between $\mathrm{Vr}$ and $\mathrm{NVr}$ aphids at a control temperature of $25^{\circ} \mathrm{C}$ although these genes in $\mathrm{Vr}$ aphids were upregulated when subjected to thermal stress. The results are suggestive of the role of Hsps being more specific to vector response against temperature stress in comparison with virus acquisition or transmission. 
Transmission biology of vector-borne viruses is an important aspect that is instrumental to develop disease control strategies [16]. A recent review [51] highlighted the influence of abiotic stress on virus transmission, mainly by changes in the host and vector physiology status. The present experiment highlights the impact of thermal stress on the BBTV acquisition and transmission. Studies emphasizing the effect of temperature on the transmission efficiency of banana black aphids were conducted nearly a decade ago [16]. However, an important aspect that always needs to be addressed is the concentration of the BBTV titer carried by black aphids under different temperature stress conditions. By absolute quantification using qPCR analysis, maximum virus titer in adult aphids was noted at $25^{\circ} \mathrm{C}$, showing maximum acquisition and inoculation by $P$. nigronervosa. At $38^{\circ} \mathrm{C}$, virus transmission by the aphids was delayed because the virus concentration in the vector was much less. This is well supported by the fact that vectors with higher viral copy have higher transmission rate [31]. However, the virus concentration was the lowest in the aphids at $15{ }^{\circ} \mathrm{C}$, leading to inefficiency of transmission. A previous experiment conducted by [52] clarified that virus transmission was impossible when the aphids were treated at $16^{\circ} \mathrm{C}$ continuously for 1 month, showing zero transmission rate. However, when the experiment was conducted for only $2 \mathrm{~h}$ or $24 \mathrm{~h}$, the virus showed $100 \%$ transmission rate. Such observations may be due to the reduced activity of the aphid vector at low temperatures [49]. In addition, the increased mortality of adult aphids at lower temperatures can also be a potential reason for such inefficiency in transmission. There are reports indicating higher transmission of BBTV by adult aphids at $25^{\circ} \mathrm{C}$ and $30{ }^{\circ} \mathrm{C}$ compared to lower temperatures [16,52].It has been well documented that in India the population of P.nigronervosa is higher during the summer season only and predominant in plantations lower than $1000 \mathrm{~m}$ [53]. This led to a conflict with our study that extreme temperature regimes where the aphids cannot survive or are under a critical stress situation may also become a critical point for the virus to spread and survive. Hence our results were incompatible with the above study and showed very low aphid survivability at $5{ }^{\circ} \mathrm{C}$ and low population activity at $15^{\circ} \mathrm{C}$ and $38^{\circ} \mathrm{C}$.

To conclude, our research findings reveal the intricate interactions between BBTV and its vector, P.nigronervosa. Although a great deal of advancement has been made over the past years in the virus-vector relationship, limited efforts are directed towards delineating the interaction between BBTV and P.nigronervosa. Again, the vectors' role in virus transmission are becoming more apparent day by day because the use of insecticides has been notoriously increasing, which are often environmentally toxic and expensive. It is also certain that the current disturbances in the global climatic scenario will have an impact on insect vector biology and ultimately the worldwide spread of viral diseases. The present study reveals that acquisition of BBTV modifies P.nigronervosa, thus accelerating its development and resulting in higher thermal susceptibility. It can be presumed that this kind of vector modification could be due to the elevated transcript level of Hsps induced by virus acquisition. Our results also provide a deeper insight into the role of temperature on virus acquisition and transmission, which is an important consideration while modeling viral disease epidemiology. However, a better understanding of the functional role of heat shock proteins in virus replication might help in deploying novel strategies for effective management of BBTV. Since BBTV is quarantined pest and of worldwide importance, continued attention to the interactions between BBTV and its vector will bring a deeper insight into our understanding of their epidemiology and potentially help to ameliorate decision support tools in the future.

Author Contributions: Conceptualization, S.C. and J.T.; methodology, S.C. and M.B.; writingoriginal draft preparation, S.S. and S.C.; validation, J.T. and M.B.; data curation, M.R. and M.B.; visualization, M.B.; supervision, J.T.; funding acquisition, J.T.; resource, J.T.; review and editing, J.T.; funding acquisition, J.T. All authors have read and agreed to the published version of the manuscript.

Funding: This research received no external funding.

Institutional Review Board Statement: Not Applicable. 
Informed Consent Statement: Not Applicable.

Data Availability Statement: The sequence determined as part of this study has been deposited in GenBank under accession numbersMW241549-MW24152, MT109277, and MT670274.

Acknowledgments: The first author thankfully acknowledges Bidhan Chandra Krishi Viswavidyalaya (ICAR-accredited State Agricultural University) for providing the Senior Research Fellowship to carry out this research work.

Conflicts of Interest: The authors declare no conflict of interest.

\section{References}

1. Stout, M.J.; Thaler, J.S.; Thomma, B.P. Plant-mediated interactions between pathogenic microorganisms and herbivorous arthropods. Annu. Rev. Èntomol. 2006, 51, 663-689. [CrossRef]

2. Belliure, B.; Janssen, A.; Maris, P.C.; Peters, D.; Sabelis, M.W. Herbivore arthropods benefit from vectoring plant viruses. Ecol. Lett. 2004, 8, 70-79. [CrossRef]

3. Hatcher, P.E. Three-way interactions between plant pathogenic fungi, herbivorous insects and their host plants. Biol. Rev. 1995, 70, 639-694. [CrossRef]

4. Hodge, S.; Powell, G. Do plant viruses facilitate their aphid vectors by inducing symptoms that alter behavior and performance? Environ. Entomol. 2008, 37, 1573-1581. [CrossRef] [PubMed]

5. Johnson, S.; Douglas, A.E.; Woodward, S.; Hartley, S.E. Microbial impacts on plant-herbivore interactions: The indirect effects of a birch pathogen on a birch aphid. Oecologia 2003, 134, 388-396. [CrossRef] [PubMed]

6. Hogenhout, S.A.; Ammar, E.D.; Whitfield, A.E.; Redinbaugh, M.G. Insect vector interactions with persistently trans-mitted viruses. Annu. Rev. Phytopathol. 2008, 46, 327-359. [CrossRef]

7. Ng, J.C.K.; Perry, K.L. Transmission of plant viruses by aphid vectors. Mol. Plant Pathol. 2004, 5, 505-511. [CrossRef]

8. Miller, J.W.; Coon, B.F. The Effect of Barley Yellow Dwarf Virus on the Biology of Its Vector the English Grain Aphid, Macrosiphum granarium12. J. Econ. Èntomol. 1964, 57, 970-974. [CrossRef]

9. Wijkamp, I.; Goldbach, R.; Peters, D. Propagation of tomato spotted wilt virus in Frankliniella occidentalis does neither result in pathological effects nor in transovarial passage of the virus. Ėntomol. Exp. Appl. 1996, 81, 285-292. [CrossRef]

10. Fereres, A.; Kampmeier, G.E.; Irwin, M.E. Aphid attraction and preference for soybean and pepper plants infected with Potyviridae. Ann. Entomol. Soc. 1999, 92, 542-548. [CrossRef]

11. Medina-Ortega, K.J.; Bosque-Perez, N.A.; Ngumbi, E.; Jimenez-Martinez, E.S.; Eigenbrode, S.D. Rhopalosiphum padi (Hemip-tera: Aphididae) responses to volatile cues from barley yellow dwarf-virus infected wheat. Environ. Entomol. 2009, 38, 836-845. [CrossRef]

12. Stafford, C.A.; Walker, G.P.; Ullman, D.E. Infection with a plant virus modifies vector feeding behavior. Proc. Natl. Acad. Sci. USA 2011, 108, 9350-9355. [CrossRef] [PubMed]

13. Froissart, R.; Duomayrou, J.; Vuillaume, F.; Alizon, S.; Michalakis, Y. The virulence-transmission trade-off in vector-borne plant viruses: A review of (non) exisiting studies. Philos. Trans. R. Soc. BBiol. Sci. 2010, 365, 1907-1918. [CrossRef]

14. Pusag, J.C.A.; Jahan, S.H.; Lee, K.-S.; Lee, S.; Lee, K.-Y. Upregulation of temperature susceptibility in Bemisia tabaci upon acquisition of Tomato yellow leaf curl virus (TYLCV). J. Insect Physiol. 2012, 58, 1343-1348. [CrossRef] [PubMed]

15. Harrison, B.D. Plant virus ecology: Ingredients, interactions and environmental influences. Ann. Appl. Biol. 1981, 99, 195-209. [CrossRef]

16. Anhalt, M.D.; Almeida, R. Effect of Temperature, Vector Life Stage, and Plant Access Period on Transmission of Banana bunchy top virus to Banana. Phytopathology 2008, 98, 743-748. [CrossRef]

17. Fereres, A.; Peñaflor, M.F.G.; Favaro, C.F.; Azevedo, K.E.; Landi, C.H.; Maluta, N.K.; Lopes, J.R. Tomato infection by whiteflytransmitted circulative and non-circulative viruses induces contrasting changes in plant volatiles and vector behav-iour. Viruses 2016, 8, 225. [CrossRef]

18. Duman, J.G. Antifreeze and Ice Nucleator Proteins in Terrestrial Arthropods. Annu. Rev. Physiol. 2001, 63, 327-357. [CrossRef] [PubMed]

19. Storey, K.B. Organic Solutes in Freezing Tolerance. Comp. Biochem. Physiol. Part A Physiol. 1997, 117, 319-326. [CrossRef]

20. Wang, H.-S.; Kang, L. Effect of cooling rates on the cold hardiness and cryoprotectant profiles of locust eggs. Cryobiology 2005, 51, 220-229. [CrossRef]

21. Zhao, L.; Jones, W.A. Expression of heat shock protein genes in insect stress responses. Invertebr. Surviv. J. 2012, 9, 93-101.

22. Feder, M.E.; Hofmann, G.E. Heat-shock proteins, molecular chaperones, and the stress response: Evolutionary and Ecological Physiology. Annu. Rev. Physiol. 1999, 61, 243-282. [CrossRef]

23. Kim, K.K.; Kim, R.; Kim, S.-H. Crystal structure of a small heat-shock protein. Nat. Cell Biol. 1998, 394, 595-599. [CrossRef] 
24. Sørensen, J.G.; Kristensen, T.N.; Loeschcke, V. The evolutionary and ecological role of heat shock proteins. Ecol. Lett. 2003, 6, 1025-1037. [CrossRef]

25. Santoro, M.G.; Amici, C.; Rossi, A. Role of Heat Shock Proteins in Viral Infection. In Prokaryotic and Eukaryotic Heat Shock Proteins in Infectious Disease. Heat Shock Proteins; Pockley, A., Calderwood, S., Santoro, M., Eds.; Springer: Dordrecht, The Netherlands, 2009; Volume 4, pp. 51-84.

26. Hooks, C.R.R.; Fukuda, S.; Perez, E.A.; Manandhar, R.; Wang, K.-H.; Wright, M.G.; Almeida, R.P.P. Aphid Transmission of Banana Bunchy Top Virus to Bananas After Treatment with a Bananacide. J. Econ. Ėntomol. 2009, 102, 493-499. [CrossRef]

27. Harding, R.M.; Burns, T.M.; Dale, J.L. Virus-like particles associated with banana bunchy top disease contain small single stranded DNA. J. Gen. Virol. 1991, 72, 225-230. [CrossRef]

28. Burns, T.M.; Harding, R.M.; Dale, J.L. Evidence that banana bunchy top virus has a multiple component genome. Arch Virol. 1994, 137, 371-380. [CrossRef] [PubMed]

29. Wanitchakorn, R.; Hafner, G.J.; Harding, R.M.; Dale, J.L. Functional analysis of proteins encoded by banana bunchy top virus DNA-4 to-6. Microbiol. 2000, 81, 299-306. [CrossRef]

30. Lowe, S.; Browne, M.; Boudjelas, S.; De Poorter, M. 100 of the World's Worst Invasive Alien Species: A Selection from the Global Invasive Species Database; The Invasive Species Specialist Group (ISSG): Auckland, New Zealand, 2000; Volume 12, p. 12.

31. Jebakumar, R.M.; Balasubramanian, V.; Selvarajan, R. Virus titre determines the efficiency of Pentalonia nigronervosa (Aphididae: Hemiptera) to transmit banana bunchy top virus. Virus Dis. 2018, 29, 499-505. [CrossRef]

32. Rubinstein, G.; Czosnek, H. Long-term association of tomato yellow leaf curl virus with its whitefly vector Bemisia tabaci: Effect on the insect transmission capacity, longevity and fecundity. J. Gen. Virol. 1997, 78, 2683-2689. [CrossRef]

33. Islam, M.N.; Naqvi, A.R.; Jan, A.T.; Mohd, Q.; Haq, R. Genetic diversity and possible evidence of recombination among Banana Bunchy Top Virus (BBTV) isolates. Int. Res. J. Microbiol. 2010, 1, 1-12.

34. Watanabe, S.; Bressan, A. Tropism, compartmentalization and retention of banana bunchy top virus (Nanoviridae) in the aphid vector Pentalonia nigronervosa. J. Gen. Virol. 2013, 94, 209-219. [CrossRef]

35. Shirima, R.R.; Maeda, D.G.; Kanju, E.; Ceasar, G.; Tibazarwa, F.I.; Legg, J.P. Absolute quantification of cassava brown streak virus mRNA by real-time qPCR. J. Virol. Methods 2017, 245, 5-13. [CrossRef]

36. R. Core Team. R: A Language and Environment for Statistical Computing. 2013. Available online: https://cran.r-project.org/bin/ windows/base/old/3.4.3/ (accessed on 30 November 2017).

37. De Mendiburu Delgado, F. Una Herramienta de Análisis Estadístico Para la Investigación Agrícola; Repositorioslatino Americanos, National University of Engineering (Peru): 2009. Available online: https://repositorioslatinoamericanos.uchile.cl/handle/2250 /2356485 (accessed on 4 August 2021).

38. Wickham, H. The tidyverse. $R$ Package Ver. 2017, 1, 836.

39. Li, M.; Liu, J.; Liu, S.-S. Tomato yellow leaf curl virus infection of tomato does not affect the performance of the Q and ZHJ2 biotypes of the viral vector Bemisia tabaci. Insect Sci. 2010, 18, 40-49. [CrossRef]

40. Czosnek, H.; Ghanim, M.; Morin, S.; Rubinstein, G.; Fridman, V.; Zeidan, M. Whiteflies: Vectors, and victims (?), of geminiviruses. Adv. Virus Res. 2001, 57, 291-322. [PubMed]

41. Rajan, P. Biology of Pentalonia nigronervosa f. caladii van der Goot, vector of 'katte' disease of cardamom. J. Plant. Crops. 1981, 9 , 34-41.

42. Nancy, J. Movement of Banana Bunchy Top Virus and Its Relationship with Its Aphid Vector (Pentalonia nigronervosa). Master's Thesis, Bharathidasan University, Tiruchirapalli, India, 2003.

43. Kang, L.; Chen, B.; Wei, J.; Liu, T.-X. Roles of Thermal Adaptation and Chemical Ecology in Liriomyza Distribution and Control. Annu. Rev. Èntomol. 2009, 54, 127-145. [CrossRef]

44. Hoffmann, A.A.; Sorensen, J.G.; Loeschcke, V. Adaptation of Drosophila to temperature extremes: Bringing together quanti-tative and molecular approaches. J. Therm. Biol. 2003, 28, 175-216. [CrossRef]

45. Gu, J.; Huang, L.X.; Shen, Y.; Huang, L.H.; Feng, Q.L. Hsp70 and small Hsps are the major heat shock protein members in-volved in midgut metamorphosis in the common cutworm, Spodoptera litura. Insect Mol. Biol. 2012, 5, 535-543. [CrossRef]

46. Hayward, S.A.L.; Pavlidesb, S.C.; Tammariellob, S.P.; Rineharta, J.P.; Denlinger, D.L. Temporal expression patterns of dia-pauseassociated genes in flesh fly pupae from the onset of diapause through post-diapause quiescence. J. Insect. Physiol. 2005, 51, 631-640. [CrossRef] [PubMed]

47. Li, Y.; Zhao, Q.; Duan, X.; Song, C.; Chen, M. Transcription of four Rhopalosiphum padi (L.) heat shock protein genes and their responses to heat stress and insecticide exposure. Comp. Biochem. Physiol. Part A Mol. Integr. Physiol. 2017, 205, 48-57. [CrossRef]

48. Lü, Z.-C.; Wan, F.-H. Differential gene expression in whitefly (Bemisia tabaci) B-biotype females and males under heat-shock condition. Comp. Biochem. Physiol. Part D Genom. Proteom. 2008, 3, 257-262. [CrossRef] [PubMed]

49. Porras, M.F.; Navas, C.A.; Marden, J.H.; Mescher, M.C.; De Moraes, C.M.; Pincebourde, S.; Sandoval-Mojica, A.; Raygoza-Garay, J.A.; Holguin, G.A.; Rajotte, E.G.; et al. Enhanced heat tolerance of viral-infected aphids leads to niche expansion and reduced interspecific competition. Nat. Commun. 2020, 11, 1-9. [CrossRef] [PubMed]

50. Xu, N.; Zhong, T.; Feng, W.; Zhou, G. Tolerance and responsive gene expression of Sogatella furcifera under extreme temperature stresses are altered by its vectored plant virus. Sci. Rep. 2016, 6, 31521. [CrossRef] 
51. Van Munster, M. Impact of abiotic stresses on plant virus transmission by aphids. Viruses 2020, 12, 216. [CrossRef]

52. Wu, R.Y.; Su, H.J. Transmission of banana bunchy top virus by aphids to banana plantlets from tissue culture. Bot. Bull. Acad. Sin. 1990, 31, 7-10

53. Ghosh, A.; Chakrabarti, S.; Mandal, B.; Kumar, N.K. Aphids as vectors of the plant viruses in India. In A Century of Plant Virology in India, 1st ed.; Mandal, B., Govind Pratap, R., Virendram, K.B., Rakesh, K.J., Eds.; Springer: Singapore, 2017 ; pp. 515-536. 